\title{
KUAT TEKAN DAN POROSITAS BETON POROUS DENGAN BAHAN PENGISI STYROFOAM
}

\author{
Arusmalem Ginting \\ Jurusan Teknik Sipil, Fakultas Teknik, Universitas Janabadra \\ Jl. Tentara Rakyat Mataram No. 55-57, Yogyakarta \\ E-mail : agintingm@yahoo.com
}

\begin{abstract}
ABSTRAK
Penggunaan faktor air semen yang terlalu tinggi pada beton porous mengakibatkan pasta semen terlalu cair dan mengalir meninggalkan agregat sehingga terjadi endapan di bagian dasar. Untuk mengatasi endapan diperlukan bahan pengisi pori antar agregat kasar yang masih memungkinkan air untuk menembus beton, dan penggunaan faktor air semen (fas) yang sekecil mungkin. Butiran styrofoam adalah butiran yang berdiameter hampir seragam sehingga pori-pori antar butirannya masih dapat dilalui air sehingga dapat digunakan sebagai bahan pengisi beton porous. Agregat kasar yang digunakan pada penelitian ini berupa batu pecah (split) dengan berat $1466 \mathrm{~kg} / \mathrm{m}^{3}$. Rasio agregat kasar dengan semen yang digunakan adalah: 3,5; 4,0; 4,5; dan 5,0, dan dengan faktor air semen (fas) 0,25 dan 0,30. Bahan tambah yang digunakan adalah SikaCim Concrete Additive sebesar $7,5 \mathrm{ml} / \mathrm{kg}$ semen. Bahan pengisi styrofoam yang digunakan sebanyak $3,4 \mathrm{~kg} / \mathrm{m}^{3} \mathrm{beton}$. Benda uji berupa silinder beton dengan diameter $15 \mathrm{~cm}$ dan tinggi $30 \mathrm{~cm}$. Jumlah benda uji untuk setiap variasi campuran sebanyak 3 buah dan total benda uji sebanyak 24 buah. Perawatan dilakukan dengan merendam benda uji dalam bak yang berisi air. Pengujian kuat tekan beton dan porositas dilakukan setelah beton berumur 28 hari. Dari hasil penelitian ini dapat disimpulkan bahwa kuat tekan beton porous dengan bahan pengisi styrofoam mengalami penurunan seiring dengan meningkatnya rasio agregat/semen. Kuat tekan beton porous dengan faktor air semen (fas) 0,25 lebih rendah dari fas 0,30 . Porositas beton porous mengalami peningkatan seiring dengan meningkatnya rasio agregat/semen. Porositas beton porous dengan faktor air semen (fas) 0,25 lebih tinggi dari fas 0,30 . Berat volume beton porous mengalami penurunan seiring dengan meningkatnya rasio agregat/semen.
\end{abstract}

Kata kunci : beton porous, kuat tekan, porositas

\begin{abstract}
Using water-cement ratio is too high on porous concrete result cement paste too fluid and will drain away from the aggregate particles and cause settlement of the cement grout at the base. To reduce settlement of the cement grout, needed material to fill the pores between coarse aggregate which can drain water from the concrete, and usage water-cement ratio (wcr) smallest. Grains of styrofoam almost uniform diameter so that the pores between the grains still permeable so that it can be used as filler for porous concrete. Coarse aggregate used in this study are crushed stone (split) with a density $1466 \mathrm{~kg} / \mathrm{m}^{3}$. Coarse aggregate-cement weight ratio used in this study were: 3,5; 4,0; 4,5; and 5,0, the water-cement ratio (wcr) 0,25 and 0,30. Chemical admixtures used are SicaCim Concrete Additive, with a dose $7.5 \mathrm{ml} / \mathrm{kg}$ of cement. The samples used in this research were concretes cylinder $150 \mathrm{~mm}$ x $300 \mathrm{~mm}$. There were 3 specimens of each variation and the total of specimens were 24. Curing concrete test specimens made by soaking the specimen in the curing box. Compressive strength and porosity of porous concrete testing was carried out after 28 days age. From these results can be concluded that the compressive strength of porous concrete with styrofoam as filler is decreased with increasing aggregate / cement ratio. Compressive strength of porous concrete with water cement ratio (wcr) 0.25 lower than 0.30 . Porosity of porous concrete increased with increasing aggregate / cement ratio. Porosity of porous concrete with water cement ratio (WCR) 0.25 higher than 0.30. Unit weight of porous concrete decreased with increasing aggregate / cement ratio.
\end{abstract}

Key words : porous concrete, compressive strength, porosity 


\section{PENDAHULUAN}

\subsection{Latar Belakang}

Penggunaan beton konvensional yang terus meningkat mengakibatkan lapisan kedap air semakin luas, sehingga air hujan tidak dapat berinfiltrasi ke dalam tanah dan mengakibatkan limpasan permukaan (surface runoff) menjadi lebih besar. Hal ini mengakibatkan muka air tanah menjadi turun dan terjadi genangan atau banjir pada musim hujan.

Beton porous adalah jenis beton khusus dengan porositas tinggi yang diaplikasikan sebagai plat beton yang memungkinkan air hujan dan air dari sumbersumber lain untuk dapat melewatinya, sehingga mengurangi limpasan permukaan dan meningkatkan muka air tanah. Porositas tinggi tercapai karena rongga yang saling berhubungan. Biasanya beton porous menggunakan sedikit atau tanpa agregat halus dan memiliki cukup pasta semen untuk melapisi permukaan agregat kasar dan untuk menjaga interkonektivitas pori. Beton porous secara tradisional digunakan untuk area parkir, di daerah lampu lalu lintas, dan trotoar untuk pejalan kaki (NRMCA, 2004).

Beton porous memiliki banyak nama yang berbeda diantaranya adalah beton tanpa agregat halus (zero-fines concrete), beton yang dapat tembus (pervious concrete), dan beton berpori (porous concrete).

Kuat tekan beton tanpa pasir lebih rendah dari kuat tekan beton normal konvensional karena peningkatan porositas. Kuat tarik dan kuat lentur beton tanpa pasir juga jauh lebih rendah dari beton konvensional (Abadjieva dan Sephiri, 2000).

Faktor air semen untuk beton non pasir bukan faktor utama untuk mengontrol sifat kekuatan. Faktor yang lebih penting adalah perbandingan agregat dengan semen. Ada suatu faktor air semen optimum yang memberikan kekuatan dan kepadatan maksimum. Penggunaan faktor air semen lebih tinggi dari 0,45 mengakibatkan pasta semen menjadi terlalu cair, dan akan mengalir meninggalkan agregat dan menyebabkan pengendapan pasta semen di dasar. Dengan faktor air semen yang lebih rendah dari 0,45 pasta tidak akan cukup untuk melapisi agregat. Faktor air semen optimum memungkinkan pasta semen untuk melapisi agregat secara seragam. Faktor air semen optimum untuk perbandingan agregat dengan semen 6:1 and 7:1 adalah sekitar 0,45 (Abadjieva dan Sephiri, 2000).

Untuk mengatasi endapan di bagian dasar beton porous akibat mengalirnya pasta semen perlu bahan pengisi pori antar agregat kasar yang masih memungkinkan air untuk menembus beton, dan penggunaan faktor air semen (fas) yang sekecil mungkin.

Kuat Tekan Dan Porositas Beton Porous Dengan Bahan Pengisi Styrofoam 77 
Butiran styrofoam adalah butiran yang berdiameter hampir seragam sehingga pori-pori antar butirannya masih dapat dilalui air sehingga dapat digunakan sebagai bahan pengisi beton porous. Styrofoam termasuk dalam kategori polimer sintetik berbahan baku monomer berbasis etilena yang berasal dari perengkahan minyak bumi. Styrofoam tahan terhadap asam, basa, dan zat pengarat (korosif) lainnya.

Penggunaan faktor air semen (fas) yang sekecil mungkin dapat dilakukan dengan menggunakan water reducing admixtures. Berdasarkan uraian di atas maka dilakukan penelitian mengenai kuat tekan dan porositas beton porous dengan bahan pengisi styrofoam.

a. Tujuan Penelitian

Tujuan dari penelitian kuat tekan dan porositas beton porous dengan bahan pengisi styrofoam ini adalah sebagai berikut.

1. Untuk mengetahui kuat tekan beton porous dengan bahan pengisi styrofoam.

2. Untuk mengetahui porositas beton porous dengan bahan pengisi styrofoam.

b. Ruang Lingkup

Ruang lingkup pada penelitian ini adalah sebagai berikut:

1. Semen yang digunakan adalah semen Portland tipe I dengan merk dagang Holcim.

2. Agregat kasar yang digunakan berupa batu pecah (split) dari Clereng, Kulon Progo, Yogyakarta.

3. Rasio agregat kasar dengan semen yang digunakan adalah: 3,5; 4,0; 4,5; dan 5,0.

4. Faktor air semen yang digunakan adalah 0,25 dan 0,30 .

5. Bahan tambah yang digunakan adalah SikaCim Concrete Additive sebesar 7,5 ml $/ \mathrm{kg}$ semen.

6. Penambahan styrofoam yang digunakan adalah $3,4 \mathrm{~kg} / \mathrm{m}^{3}$ beton.

7. Jumlah benda uji untuk setiap variasi campuran sebanyak 3 buah.

8. Benda uji berupa silinder beton dengan diameter $15 \mathrm{~cm}$ dan tinggi $30 \mathrm{~cm}$ sebanyak 24 buah.

9. Perawatan dilakukan dengan merendam benda uji dalam bak yang berisi air.

10. Pengujian porositas dan kuat tekan beton dilakukan setelah beton berumur 28 hari.

11. Matrik benda uji yang digunakan pada penelitian ini dapat dilihat pada Tabel 1. 
Tabel 1. Matrik benda uji

\begin{tabular}{|c|c|c|c|c|c|c|c|c|}
\hline No. & $\begin{array}{c}\text { Rasio } \\
\text { Agregat/ } \\
\text { Semen }\end{array}$ & $\begin{array}{l}\text { Semen } \\
(\mathrm{kg})\end{array}$ & $\begin{array}{c}\text { Agregat } \\
\text { kasar (Split) } \\
\quad(\mathrm{kg})\end{array}$ & $\begin{array}{c}\text { SikaCim } \\
\text { Concrete } \\
\text { Additive } \\
\text { (liter) }\end{array}$ & FAS & $\begin{array}{c}\text { Air } \\
\text { (liter) }\end{array}$ & $\begin{array}{l}\text { Styrofoam } \\
(\mathrm{kg})\end{array}$ & $\begin{array}{c}\text { Benda uji } \\
\text { silinder } \\
\text { (buah) }\end{array}$ \\
\hline 1 & \multirow{2}{*}{3,5} & \multirow{2}{*}{419} & \multirow{2}{*}{1466} & \multirow{2}{*}{3,141} & 0,25 & 105 & 3,4 & 3 \\
\hline 2 & & & & & 0,30 & 126 & 3,4 & 3 \\
\hline 3 & \multirow{2}{*}{4,0} & \multirow{2}{*}{366} & \multirow{2}{*}{1466} & \multirow{2}{*}{2,749} & 0,25 & 92 & 3,4 & 3 \\
\hline 4 & & & & & 0,30 & 110 & 3,4 & 3 \\
\hline 5 & \multirow{2}{*}{4,5} & \multirow{2}{*}{326} & \multirow{2}{*}{1466} & \multirow{2}{*}{2,443} & 0,25 & 81 & 3,4 & 3 \\
\hline 6 & & & & & 0,30 & 98 & 3,4 & 3 \\
\hline 7 & \multirow{2}{*}{5,0} & \multirow{2}{*}{293} & \multirow{2}{*}{1466} & \multirow{2}{*}{2,199} & 0,25 & 73 & 3,4 & 3 \\
\hline 8 & & & & & 0,30 & 88 & 3,4 & 3 \\
\hline & & & & & & & & 24 \\
\hline
\end{tabular}

\section{TINJAUAN PUSTAKA}

\subsection{Beton Porous}

Beton non pasir terdiri dari aglomerasi agregat kasar berukuran tunggal yang diselimuti dengan lapisan pasta semen tipis sekitar 1,3 mm (Neville dan Brooks, 2010).

Berdasarkan ACI 522R-10 mix design untuk pervious concrete terdiri dari: semen (270 - $415 \mathrm{~kg})$, agregat (1190 - $1480 \mathrm{~kg})$, faktor air semen $(0,27-0,34)$, perbandingan berat pasir dan kerikil ( 0 sampai $1: 1$ ). Menggunakan chemical admixtures. Penambahan pasir akan menurunkan kadar pori dan meningkatkan kuat tekan.

Penggunaan beton non pasir sebagai bahan perkerasan sangat terbatas dan belum lama dikembangkan untuk aplikasi tertentu. Namun, beton non pasir telah digunakan secara luas sebagai bahan bangunan struktural di Eropa, Australia dan Timur Tengah lebih dari 70 tahun (Macintosh dkk, 1965, dalam Harber, 2005). Penggunaan paling awal beton non pasir terjadi di Inggris pada tahun 1852 dengan pembangunan dua rumah tinggal dan krib laut sepanjang $61 \mathrm{~m}$ dan lebar 2,15 m (Francis, 1965, dalam Harber, 2005). Penggunaan beton non pasir menjadi jauh lebih luas selama kekurangan bahan setelah Perang Dunia II, untuk dinding penahan beban yang dicetak ditempat untuk bangunan tidak bertingkat dan bertingkat.

Penggunaan awal beton non pasir terutama untuk struktur dua lantai, kemudian dikembangkan untuk bangunan lima lantai di tahun 1950 dan terus berkembang. Dalam beberapa tahun terakhir beton non pasir telah digunakan sebagai bahan pendukung beban pada gedung-gedung tinggi hingga sepuluh lantai. Penggunaan yang paling luar biasa dari beton non pasir dilakukan di Stuttgart, Jerman di mana bangunan tinggi dibangun 
menggunakan beton konvensional untuk enam lantai bawah dan beton non pasir untuk tiga belas lantai atas yang tersisa (Malhotra 1976, dalam Harber, 2005).

Berat jenis beton non pasir umumnya sekitar $70 \%$ dari beton konvensional jika dibuat dengan bahan yang sama. Berat jenis beton non pasir yang menggunakan agregat konvensional bervariasi dari 1602 sampai $1922 \mathrm{~kg} / \mathrm{m}^{3}$. Agregat klinker telah diuji coba dan beton non pasir menghasilkan berat jenis $961 \mathrm{~kg} / \mathrm{m}^{3}$ (Malhotra, 1976 dalam Harber, 2005).

Abadjieva dan Sephiri (2000) melakukan penelitian beton non pasir dengan perbandingan berat agregat dengan semen dari $6: 1$ sampai $10: 1$. Kuat tekan beton non pasir pada umur 28 hari bervariasi antara 1,1 sampai $8,3 \mathrm{MPa}$, tergantung pada perbandingan agregat dengan semen, dan penurunan terjadi dengan meningkatnya perbandingan agregat dengan semen. Campuran dengan perbandingan agregat dengan semen $6: 1$ merupakan yang terkuat. Kuat tekan beton non pasir lebih rendah dari kuat tekan beton normal konvensional disebabkan oleh peningkatan porositas. Kuat tarik dan kuat lentur tertinggi terjadi pada perbandingan agregat dengan semen $7: 1$ dan penurunan terjadi dengan meningkatnya perbandingan semen dengan agregat. Kuat tarik dan kuat lentur beton non pasir lebih rendah dari beton normal konvensional.

\subsection{Bahan Susun Beton Porous}

\subsubsection{Semen Portland}

Menurut Tjokrodimuljo (1996), semen portland ialah semen hidrolis yang dihasilkan dengan menghaluskan klinker yang terutama terdiri dari silikat-silikat kalsium yang berifat hidrolis dengan gips sebagai bahan tambah. Semen jika diaduk dengan air akan membentuk pasta semen, jika diaduk dengan air kemudian ditambah pasir menjadi mortar seman, dan jika ditambah lagi dengan kerikil/batu pecah disebut beton. Semen berfungsi untuk merekatkan butir-butir agregat agar terjadi suatu massa yang kompak/padat. Semen juga berfungsi untuk mengisi rongga-rongga diantara butiran agregat.

Kekuatan semen yang telah mengeras tergantung pada jumlah air yang dipakai waktu proses hidrasi berlangsung. Pada dasarnya jumlah air yang diperlukan untuk proses hidrasi hanya kira-kira 25 persen dari berat semennya, penambahan jumlah air akan mengurangi kekuatan setelah mengeras. Kelebihan air dari yang diperlukan untuk proses hidrasi pada umumnya diperlukan pada pembuatan beton, agar adukan beton dapat dicampur dengan baik, diangkut dengan mudah, dan dapat dicetak tanpa rongga-rongga yang besar (tidak keropos). Akan tetapi, hendaknya selalu diusahakan jumlah air 
sesedikit mungkin, agar kekuatan beton tidak terlalu rendah. Pasta semen yang mengeras merupakan bagian yang porous. Konsentrasi hasil-hasil hidrasi yang padat pada seluruh ruang atau volume yang tersedia (volume yang semula ditempati oleh air dan semen) merupakan suatu nilai indeks porositas. Kuat tekan pasta semen (juga betonnya) sangat dipengaruhi oleh besar pori-pori diantara gel-gel atau pori-pori hasil hidrasi. Kelebihan air akan mengakibatkan pasta semen berpori lebih banyak, sehingga hasilnya kurang kuat dan juga lebih porous (berpori).

\subsubsection{Agregat Kasar}

Menurut Tjokrodimuljo (1996), agregat adalah butiran mineral alami yang berfungsi sebagai bahan pengisi dalam campuran mortar atau beton. Agregat menempati sekitar $70 \%$ dari volume mortar atau beton. Agregat sangat berpengaruh terhadap sifatsifat mortar/betonnya, sehingga pemilihan agregat merupakan suatu bagian penting dalam pembuatan mortar/beton.

Cara membedakan jenis agregat yang paling banyak dilakukan ialah dengan didasarkan pada ukuran butir-butirnya. Agregat yang mempunyai ukuran butir-butir besar disebut agregat kasar, sedangkan agregat yang berbutir kecil disebut agregat halus. Secara umum, agregat kasar sering disebut sebagai kerikil, kericak, batu pecah atau split. Agregat halus disebut pasir, baik berupa pasir alami yang diperoleh langsung dari sungai atau tanah galian, atau dari hasil pemecahan batu. Dalam praktek agregat umumnya digolongkan menjadi 3 kelompok, yaitu:

a. Batu, untuk besar butiran lebih dari $40 \mathrm{~mm}$.

b. Kerikil, untuk butiran antara $5 \mathrm{~mm}$ dan $40 \mathrm{~mm}$.

c. Pasir, untuk butiran antara $0,15 \mathrm{~mm}$ dan $5 \mathrm{~mm}$.

Agregat harus mempunyai bentuk yang baik (bulat atau mendekati kubus), bersih, keras, kuat, dan gradasinya baik. Agregat harus pula mempunyai kestabilan kimiawi, dan dalam hal-hal tertentu harus tahan aus dan tahan cuaca.

Agregat diperoleh dari sumber daya alam yang telah mengalami pengecilan ukuran secara alamiah (misalnya kerikil) atau dapat pula diperoleh dengan cara memecah batu alam. Agregat pecahan (kerikil maupun pasir) diperoleh dengan memecah batu menjadi berukuran butiran yang diingini dengan cara meledakkan, memecah, menyaring, dan seterusnya. Batu pecah mempunyai butir-butir yang berbentuk tajam, sehingga sedikit lebih memperkuat betonnya.

Kuat Tekan Dan Porositas Beton Porous Dengan Bahan Pengisi Styrofoam 


\subsubsection{Berat jenis agregat}

Agregat dapat dibedakan berdasarkan berat jenisnya, yaitu: agregat normal, agregat berat, dan agregat ringan.

Agregat normal adalah agregat yang berat jenisnya antara 2,5 sampai 2,7. Agregat ini biasanya berasal dari agregat granit, basalt, kuarsa, dan sebagainya. Beton yang dihasilkan berberat jenis sekitar 2,3 dengan kuat tekan antara 15 MPa sampai 40 MPa. Betonnyapun disebut beton normal.

Agregat berat berberat jenis lebih dari 2,8 misalnya magnetik $\left(\mathrm{Fe}_{3} \mathrm{O}_{4}\right)$, barytes $\left(\mathrm{BaSO}_{4}\right)$, atau serbuk besi. Beton yang dihasilkan juga berat jenisnya tinggi (sampai 5), yang efektif sebagai dinding pelindung sinar radiasi sinar $\mathrm{X}$.

Agregat ringan mempunyai berat jenis kurang dari 2,0 yang biasanya dibuat untuk non struktural, akan tetapi dapat pula untuk beton struktural atau blok dinding tembok. Kebaikannya adalah berat sendiri yang rendah sehingga strukturnya ringan dan fondasinya lebih kecil.

\subsubsection{Modulus halus butir (MHB)}

Modulus halus butir (fineness modulus) ialah suatu indeks yang dipakai untuk menjadi ukuran kehalusan atau kekasaran butir-butir agregat. Modulus halus butir (MHB) didefinisikan sebagai jumlah persen komulatif dari butir-butir agregat yang tertinggal di atas suatu set ayakan dan kemudian dibagi seratus. Susunan lubang ayakan itu ialah sebagai berikut: $40 \mathrm{~mm}, 20 \mathrm{~mm}, 10 \mathrm{~mm}, 4,80 \mathrm{~mm}, 2,40 \mathrm{~mm}, 1,20 \mathrm{~mm}, 0,60 \mathrm{~mm}, 0,30$ $\mathrm{mm}$, dan $0,15 \mathrm{~mm}$.

Makin besar nilai modulus halus menunjukkan bahwa makin besar butir-butir agregatnya. Modulus halus butir kerikil biasanya diantara 5 dan 8 .

\subsubsection{Serapan air dalam agregat}

Karena adanya udara yang terjebak dalam suatu butiran agregat ketika pembentukannya atau karena dekomposisi mineral pembentuk tertentu oleh perubahan cuaca, maka terbentuklah lubang, atau rongga kecil di dalam butiran agregat itu, yang umumnya disebut pori. Pori dalam butiran agregat mempunyai ukuran yang bervariasi, dari yang besar sehingga mampu dilihat dengan mata telanjang, sampai yang hanya dapat dilihat dengan mikroskop. Pori-pori tersebar di seluruh tubuh butiran, beberapa merupakan pori-pori tertutup dalam materi, beberapa yang lainnya terbuka terhadap permukaan butiran. Beberapa jenis agregat yang sering dipakai mempunyai volume pori tertutup sekitar 0 sampai 20 persen dari volume butirnya. 
Karena agregat menempati sampai 75 persen dari volume betonnya maka porositas agregat memberikan iuran/kontribusi pada porositas beton secara keseluruhan. Pori-pori mungkin menjadi reservoar air bebas di dalam agregat. Persentase berat air yang mampu diserap oleh suatu agregat jika direndam dalam air disebut serapan air.

Agregat yang jenuh air (pori-porinya terisi penuh oleh air), namun permukaannya kering sehingga tidak mengganggu air bebas di permukaannya disebut agregat jenuh kering muka. Air dalam agregat dikenal ada 2 macam, yaitu air yang meresap dan air yang ada di permukaan butiran. Air yang meresap berada dalam pori antar butir dan mungkin tidak tampak di permukaan, dan ini dipengaruhi oleh besar pori butiran agregatnya. Pada agregat normal kemampuan menyerap air ini sekitar 1 sampai 2 persen saja. Kemampuan menyerap air ini disebut serapan air atau daya serap suatu agregat. Adapun air yang ada di permukaan butir tampak di permukaan, dan ini dipengaruhi oleh lingkungan agregat, basah atau kering.

\subsubsection{Kadar air agregat}

Air yang ada pada suatu agregat (di lapangan) perlu diketahui untuk menghitung jumlah air yang perlu dipakai dalam campuran adukan beton dan pula untuk mengetahui berat satuan agregat. Keadaan kandungan air di dalam agregat dibedakan menjadi beberapa tingkat, yaitu:

a. Kering tungku, yaitu agregat yang benar-benar tidak berair, dan ini berarti dapat secara penuh menyerap air.

b. Kering udara, yaitu agregat yang kering permukaannya tetapi mengandung sedikit air di dalam porinya. Oleh karena itu agregat dalam tingkat ini masih dapat sedikit mengisap air.

c. Jenuh kering muka, agregat pada tingkat ini tidak ada air di permukaan tetapi butirbutirnya berisi sejumlah air. Dengan demikian butiran-butiran agregat pada tahap ini tidak menyerap dan juga tidak menambah jumlah air bila dipakai dalam campuran adukan beton.

d. Basah, yaitu agregat yang butir-butirnya mengandung banyak air, baik di permukaan maupun di dalam butiran, sehingga bila dipakai untuk campuran akan memberi air.

Dari keempat keadaan tersebut, hanya dua keadaan yang sering dipakai dalam dasar hitungan, ialah kering tungku dan jenuh kering muka, karena konstan untuk suatu agregat tertentu. Adapun kering udara dan basah yang merupakan keadaan sebenarnya di lapangan sangat bervariasi karena dipengaruhi oleh lingkungan. 
Keadaan jenuh kering muka (saturated surface dry, SSD) lebih disukai sebagai standar, karena:

a. Merupakan keadaan kebasahan agregat yang hampir sama dengan agregat dalam beton, sehingga agregat tidak akan menambah maupun mengurangi air dari pastanya.

b. Kadar air di lapangan lebih banyak yang mendekati keadaan SSD daripada yang kering tungku.

Dalam hitungan kebutuhan air pada adukan beton, biasanya agregat dianggap dalam keadaan jenuh kering muka, sehingga jika keadaan agregat di lapangan kering udara maka dalam adukan beton akan menyerap air, namun jika agregat di lapangan dalam keadaan basah maka akan menambah air. Penyerapan dan penambahan air tersebut dapat dihitung dengan Persamaan berikut ini.

$$
\mathrm{A}_{\mathrm{tamb}}=\frac{K-K_{j k m}}{100} \cdot W_{a g}
$$

Dengan:

$$
\begin{array}{ll}
\mathrm{A}_{\text {tamb }} & =\text { air tambahan dari agregat (liter) } \\
\mathrm{K} & =\text { kadar air agregat di lapangan }(\%) \\
\mathrm{K}_{\mathrm{jkm}} & =\text { kadar air agregat jenuh kering muka }(\%) \\
\mathrm{W}_{\mathrm{ag}} & =\text { berat agregat }(\mathrm{kg})
\end{array}
$$

\subsubsection{Persyaratan agregat}

Agregat untuk bahan bangunan sebaiknya dipilih yang memenuhi peryaratan sebagai berikut:

a. Butir-butirnya tajam, kuat, dan bersudut. Ukuran kekuatan agregat dapat dilakukan dengan pengujian ketahanan aus dengan mesin uji Los Angeles, atau dengan bejana Rudeloff. Berdasarkan Standar Bidang Pekerjaan Umum, persyaratan kekerasan agregat kasar untuk beton dengan mesin Los Angeles, maksimum bagian yang hancur menembus ayakan $1,7 \mathrm{~mm}$ adalah sebagai berikut:

1). Kekuatan beton sampai $10 \mathrm{MPa}$ sebesar $50 \%$

2). Kekuatan beton $10 \mathrm{MPa}-20 \mathrm{MPa}$, sebesar $40 \%$

3). Kekuatan beton di atas $20 \mathrm{MPa}$ sebesar $27 \%$

b. Tidak mengandung tanah atau kotoran lain yang lewat ayakan 0,075 mm. Pada agregat kasar kandungan kotoran ini dibatasi sampai maksimum 1\%. Jika agregat 
mengandung kotoran lebih dari batas-batas maksimum tersebut maka harus dicuci dengan air bersih.

c. Tidak mengandung garam yang mengisap air dari udara.

d. Tidak mengandung zat organis.

e. Mempunyai variasi besar butir (gradasi) yang baik sehingga rongganya sedikit.

f. Bersifat kekal, tidak hancur atau berubah karena cuaca.

g. Untuk beton dengan tingkat keawetan yang tinggi, agregat harus mempunyai tingkat reaktif yang negatif terhadap alkali.

h. Untuk agregat kasar, tidak boleh mengandung butiran-butiran yang pipih dan panjang lebih dari $20 \%$ dari berat keseluruhan.

\subsubsection{Gradasi agregat}

Gradasi adalah distribusi ukuran butiran dari agregat. Jika butir agregat memiliki ukuran yang sama (seragam) maka volume pori besar. Jika butir agregat memiliki ukuran bervariasi maka volume pori kecil, karena butiran yang kecil mengisi pori diantara butiran yang lebih besar sehingga porinya sedikit dan kepampatannya tinggi.

Gradasi kerikil berdasarkan British Standard seperti pada Gambar 1. berikut ini.

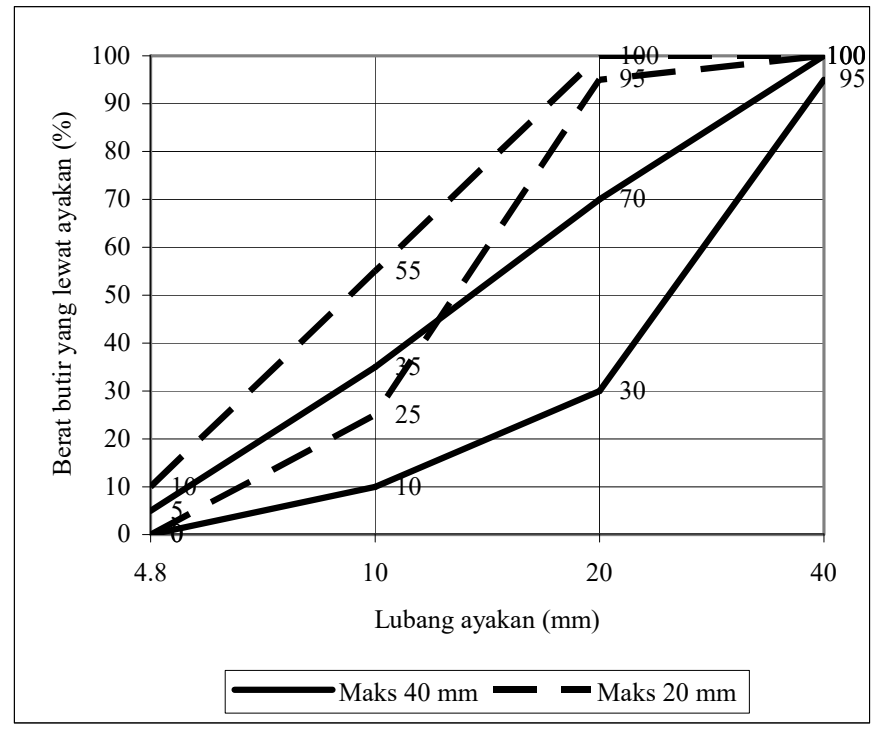

Gambar 1. Gradasi kerikil

\subsubsection{Air}

Menurut Tjokrodimuljo (1996), air diperlukan untuk berreaksi dengan semen, serta untuk menjadi bahan pelumas antara butir-butir agregat agar dapat mudah dikerjakan dan 
dipadatkan. Untuk berreaksi dengan semen, air yang diperlukan hanya sekitar $25 \%$ berat semen saja, namun dalam kenyataannya nilai faktor air semen yang dipakai sulit kurang dari 0,35. Kelebihan air ini dipakai sebagai pelumas. Tambahan air untuk pelumas ini tidak boleh terlalu banyak karena kekuatan beton akan rendah serta betonnya porous. Air yang memenuhi persyaratan sebagai air minum memenuhi syarat pula untuk bahan campuran beton. Secara umum, air yang dapat dipakai untuk bahan pencampur beton ialah air yang bila dipakai akan dapat menghasilkan beton dengan kekuatan lebih dari $90 \%$ kekuatan beton yang memakai air suling.

Dalam pemakaian air untuk beton, sebaiknya air memenuhi syarat sebagai berikut:

a. Tidak mengandung lumpur (benda melayang lainnya) lebih dari 2 gram/liter.

b. Tidak mengandung garam-garam yang dapat merusak beton (asam, zat organik, dan sebagainya) lebih dari 15 gram/liter.

c. Tidak mengandung khlorida $(\mathrm{Cl})$ lebih dari 0,5 gram/liter.

d. Tidak mengandung senyawa sulfat lebih dari 1 gram/liter.

\subsubsection{Styrofoam}

Styrofoam termasuk dalam kategori polimer sintetik dengan berat molekul tinggi. Polimer sintetik berbahan baku monomer berbasis etilena yang berasal dari perengkahan minyak bumi. Styrofoam hanya sebuah nama dalam dunia perdagangan, nama sesungguhnya adalah polystyrene atau poli (feniletena) dalam bentuk foam. Feniletena atau styrene dapat dipolimerkan dengan menggunakan panas, sinar ultra violet, atau katalis. Poli (feniletena) merupakan bahan termo plastik yang bening (kecuali jika ditambahkan pewarna atau pengisi), dan dapat dilunakkan pada suhu sekitar $100^{\circ}$ C. Poli (feniletena) tahan terhadap asam, basa dan zat pengarat (korosif) lainnya, tetapi mudah larut dalam hidrokarbon aromatik dan berklor. Dalam propanon (aseton), poli (feniletena) hanya mengembang. Penyinaran dalam waktu yang lama oleh sinar ultra ungu, sinar putih, atau panas, sedikit mempengaruhi kekuatan dan ketahanan polimer terhadap panas. Poli (feniletena) berbusa atau styrofoam diperoleh dari pemanasan poli (feniletena) yang menyerap hidrokarbon volatil. Ketika dipanasi oleh kukus (steam) butiran akan melunak, dan penguapan hidrokarbon di dalam butiran akan menyebabkan butiran mengembang (Cowd, 1991).

\section{METODOLOGI}

Sebelum dilakukan pembuatan benda uji dilakukan pengujian slump terlebih dahulu. Pembuatan benda uji silinder beton mengacu pada SNI 03-1974-1990. Cetakan 
benda uji berupa silinder dengan diameter $152 \mathrm{~mm}$ dan tinggi $305 \mathrm{~mm}$. Cetakan diisi dengan adukan beton dalam 3 lapis, setiap lapis dipadatkan dengan 25 kali tusukan secara merata, setelah itu permukaan beton diratakan dan ditutup dengan bahan kedap air.

Pada penelitian ini untuk meratakan permukaan beton porous dilakukan caping menggunakan mortar terlebih dahulu dan kemudian caping menggunakan belerang.

Perawatan beton adalah suatu pekerjaan menjaga agar permukaan beton selalu segar, lembab sampai beton dianggap cukup keras. Hal ini dimaksudkan untuk menjamin proses hidrasi semen berlangsung dengan sempurna. Selain itu perawatan juga mengurangi penyusutan akibat penguapan air berlebihan sehingga timbulnya retakanretakan dapat dihindari dan mutu beton tetap terjamin.

Metode perawatan yang digunakan dalam penelitian ini adalah dengan cara direndam dalam bak perendam berisi air pada temperatur $25^{\circ}$ C. Perawatan dimulai pada hari kedua sampai satu hari sebelum dilakukan pengujian.

Pengujian porositas dilakukan sebelum uji tekan beton dan melalui tahapan sebagai berikut, dan untuk lebih jelasnya dapat dilihat pada Gambar 2. Metode pengujian mengacu pada ACI 522R yang dimodifikasi.

a. Benda uji diletakkan di bagian bawah alat uji porositas yang berdiameter $15 \mathrm{~cm}$.

b. Ujung atasnya dimasukan pipa berdiameter $15 \mathrm{~cm}$ dengan panjang 1 meter, pada sambungan diberi plester agar tidak bocor.

c. Pipa diisi air setinggi benda uji, pipa penghubung yang satunya berdiameter $8 \mathrm{~cm}$ ditutup.

d. Pipa diisi air setinggi 1 meter penuh, kemudian penutup pipa diameter $8 \mathrm{~cm}$ dilepas, sehingga air mengalir dari dalam pipa menembus beton.

e. Waktu yang diperlukan air untuk menembus beton sampai air berkurang $50 \mathrm{~cm}$ yang telah diberi tanda dicatat.

f. Debit dihitung dari besarnya air yang berkurang dibagi waktu. 


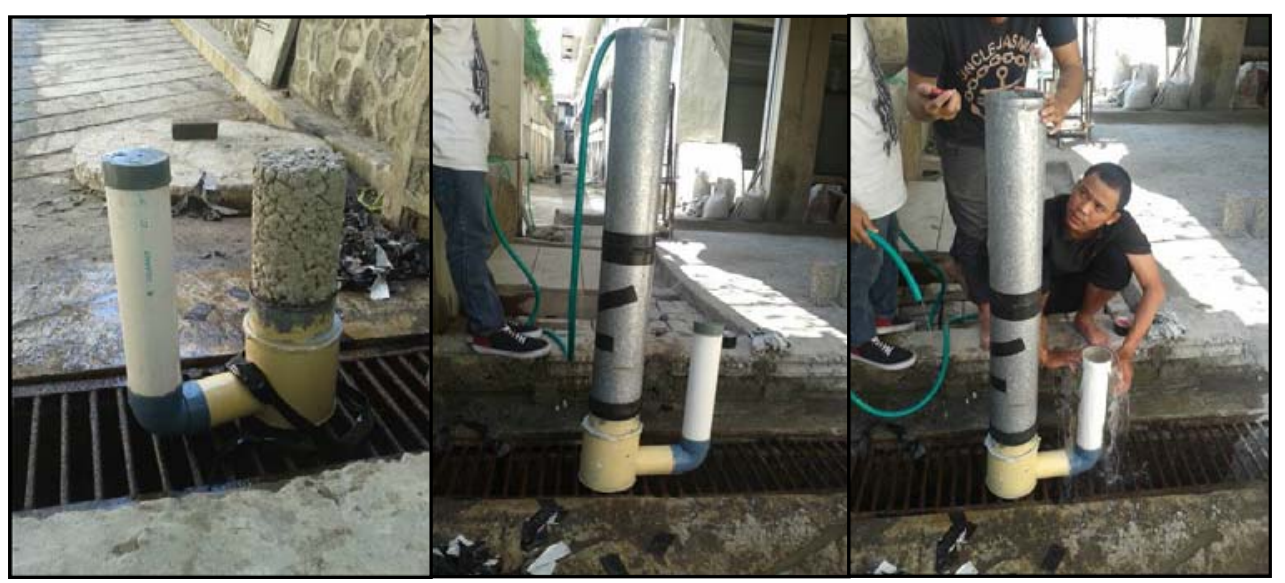

Gambar 2. Pengujian porositas

Pengujian kuat tekan beton mengacu pada SNI 03-1974-1990. Prosedur pengujian melalui tahapan sebagai berikut, dan untuk lebih jelasnya dapat dilihat pada Gambar 3.

a. Benda uji ditetakkan sentris pada mesin tekan.

b. Mesin tekan dijalankan dengan penambahan beban antara 2 sampai $4 \mathrm{~kg} / \mathrm{cm}^{2}$ per detik.

c. Pembebanan dilakukan sampai benda uji hancur.

d. Catat beban maksimum yang terjadi selama pemeriksaan benda uji.

e. Hitung kuat tekan beton yaitu besarnya beban persatuan luas.

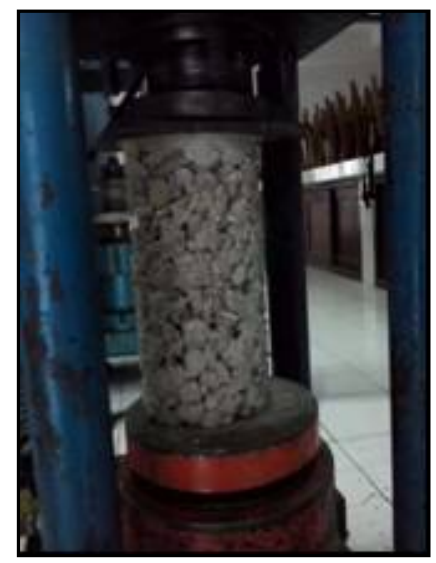

Gambar 3. Pengujian kuat tekan 


\section{HASIL DAN PEMBAHASAN}

\subsection{Agregat kasar (split)}

Hasil pemeriksaan agregat kasar (split) dapat dilihat pada Tabel 2. Dari pemeriksaan berat jenis didapat berat jenis agregat kasar (split) sebesar 2,686, berat jenis ini termasuk berat jenis normal sebab berada antara 2,5-2,7.

Nilai kadar air agregat kasar (split) sebesar $0,741 \%$ dan nilai penyerapan (absorbsi) sebesar 0,878\%. Nilai penyerapan agregat kasar lebih besar dari nilai kadar airnya sehingga akan menyerap air dari campuran. Untuk mempertahankan fas (faktor air semen) sesuai rencana maka perlu penambahan air pada campuran.

Tabel 2. Hasil pemeriksaan agregat kasar (split)

\begin{tabular}{|c|l|c|c|}
\hline No & \multicolumn{1}{|c|}{ Jenis pemeriksaan } & Hasil pemeriksaan & Satuan \\
\hline 1 & Berat jenis kering permukaan (SSD) & 2,686 & - \\
\hline 2 & Penyerapan (absorbsi) & 0,878 & $\%$ \\
\hline 3 & Berat isi & 1,533 & $\mathrm{gr} / \mathrm{cm}^{3}$ \\
\hline 4 & Kadar air & 0,741 & $\%$ \\
\hline 5 & Modulus halus butir (MHB) & 7,6449 & - \\
\hline 6 & Keausan & 15,36 & $\%$ \\
\hline
\end{tabular}

Nilai modulus halus butir (MHB) untuk agregat kasar (split) sebesar 7,6449. Agregat kasar ini tergolong agregat kasar yang baik karena mempunyai nilai MHB antara $5-8$. Keausan agregat kasar (split) sebesar 15,36\%. Nilai keausan masih lebih kecil dari $40 \%$ sehingga memenuhi syarat untuk digunakan pada beton dengan kekuatan $10 \mathrm{MPa}-$ $20 \mathrm{MPa}$.

\subsection{Nilai Slump}

Nilai slump campuran beton porous pada berbagai rasio agregat semen, faktor air semen (fas), tanpa atau dengan penambahan styrofoam adalah seperti Tabel 3. Nilai slump untuk campuran beton porous dengan bahan pengisi styrofoam pada rasio agregat semen 3,5, 4, 4,5, dan 5, dan dengan faktor air semen (fas) 0,25 dan 0,30 semuanya nol kecuali pada rasio agregat semen 5 dan fas 0,4 . Pada rasio agregat semen 5 dan fas 0,4 nilai slump sebesar $15 \mathrm{~cm}$, nilai slump ini tidak nol karena campuran terlalu kering sehingga saat pengujian slump campuran beton runtuh. 
Tabel 3. Nilai slump

\begin{tabular}{|c|c|c|c|}
\hline $\begin{array}{c}\text { No. } \\
\text { Urut }\end{array}$ & $\begin{array}{c}\text { Rasio } \\
\text { Agregat/ } \\
\text { semen }\end{array}$ & FAS & $\begin{array}{c}\text { Slump } \\
(\mathrm{cm})\end{array}$ \\
\hline 1 & \multirow{2}{*}{3,5} & 0,25 & 0 \\
\hline 2 & & 0,30 & 0 \\
\hline 3 & \multirow{2}{*}{4} & 0,25 & 0 \\
\hline 4 & 4 & 0,30 & 0 \\
\hline 5 & \multirow{2}{*}{4,5} & 0,25 & 0 \\
\hline \multirow{2nnn}{*nn}{} & & 0,30 & 0 \\
\hline 7 & \multirow{2}{*}{5} & 0,25 & 0 \\
\hline 8 & & 0,30 & 15 \\
\hline
\end{tabular}

Campuran dengan rasio agregat semen terkecil lebih encer walaupun nilai slumpnya hampir sama. Hal ini terjadi karena pada rasio agregat semen kecil jumlah semennya lebih banyak, sehingga jumlah airnya juga lebih banyak untuk faktor air semen (fas) yang sama. Untuk lebih jelasnya dapat dilihat pada Gambar 4, 5, 6, 7, 8, 9, 10, dan 11.

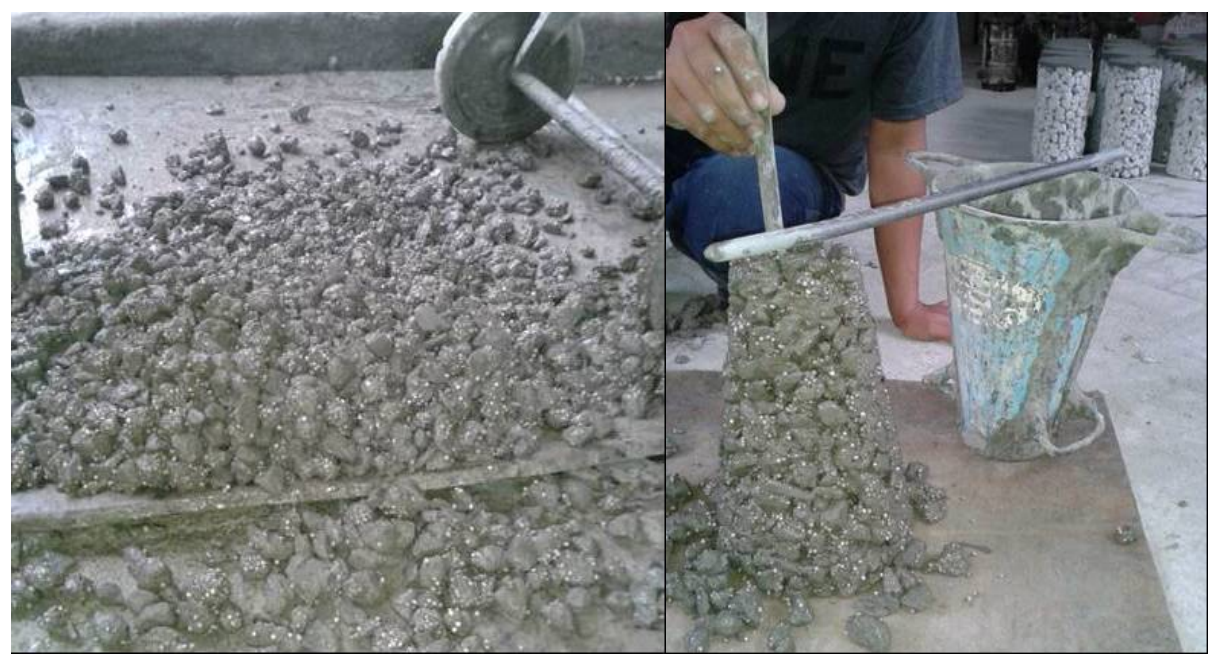

Gambar 4. Rasio agregat semen 3,5 dan fas 0,25 


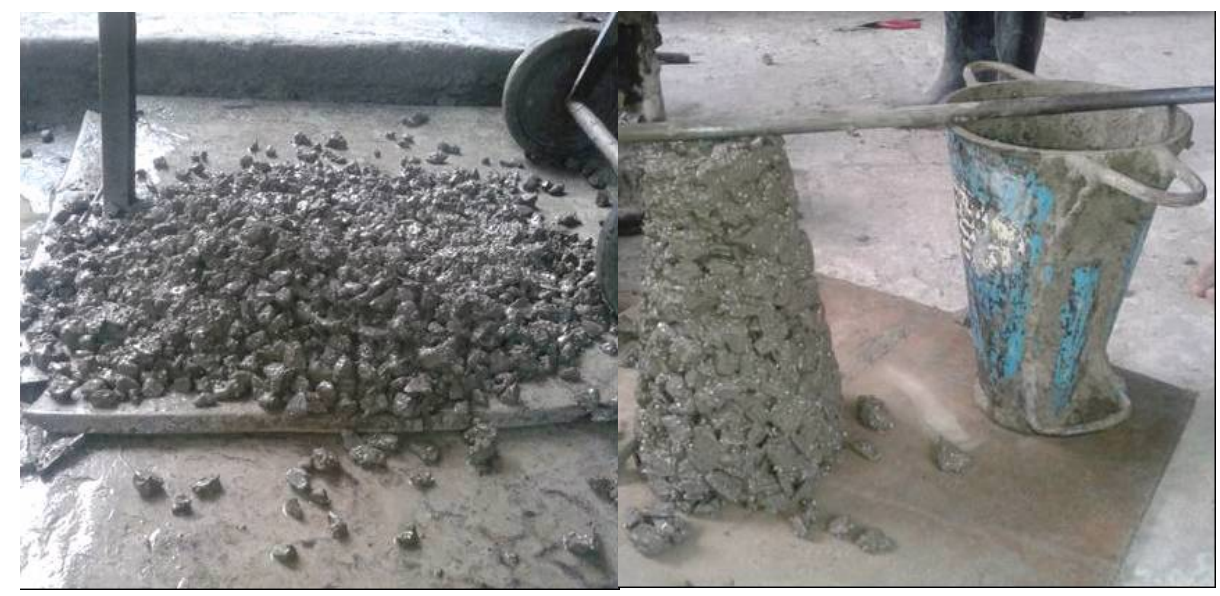

Gambar 5. Rasio agregat semen 3,5 dan fas 0,3

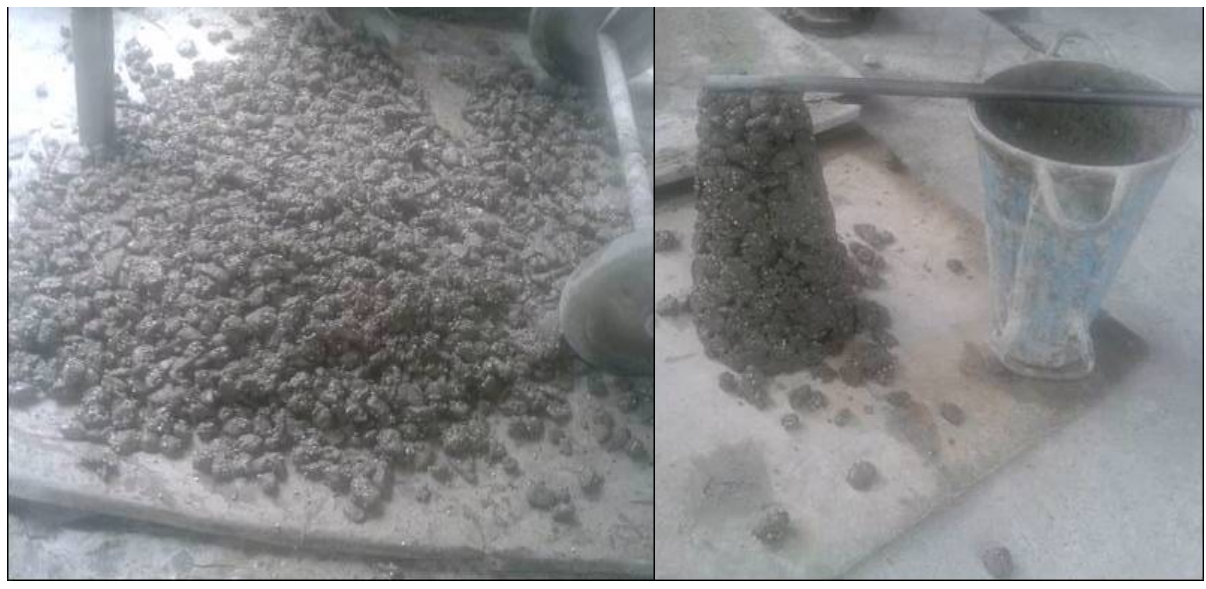

Gambar 6. Rasio agregat semen 4 dan fas 0,25

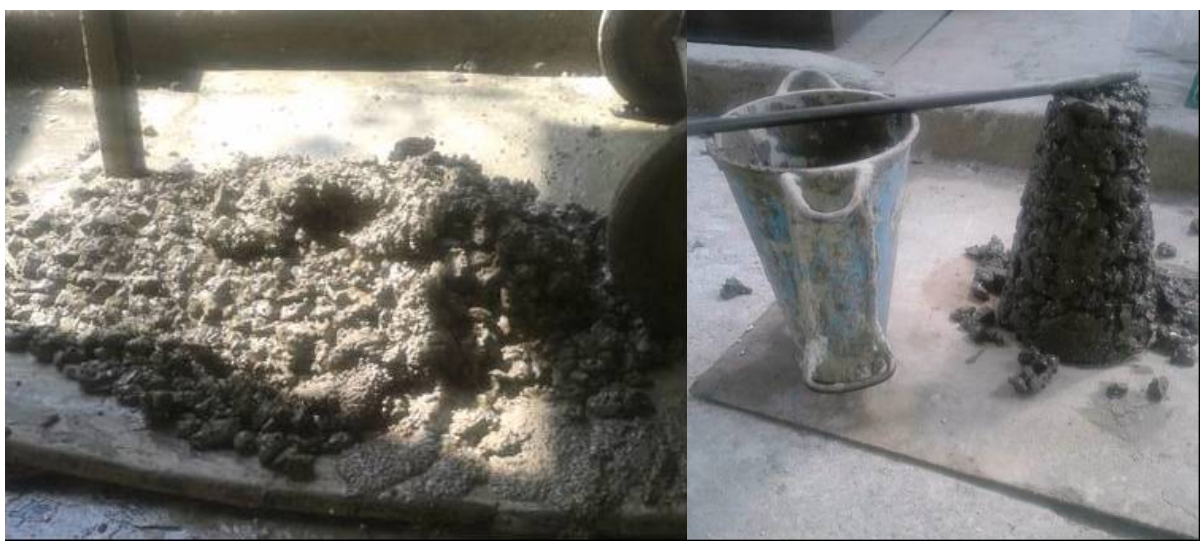

Gambar 7. Rasio agregat semen 4 dan fas 0,3

Kuat Tekan Dan Porositas Beton Porous Dengan Bahan Pengisi Styrofoam 


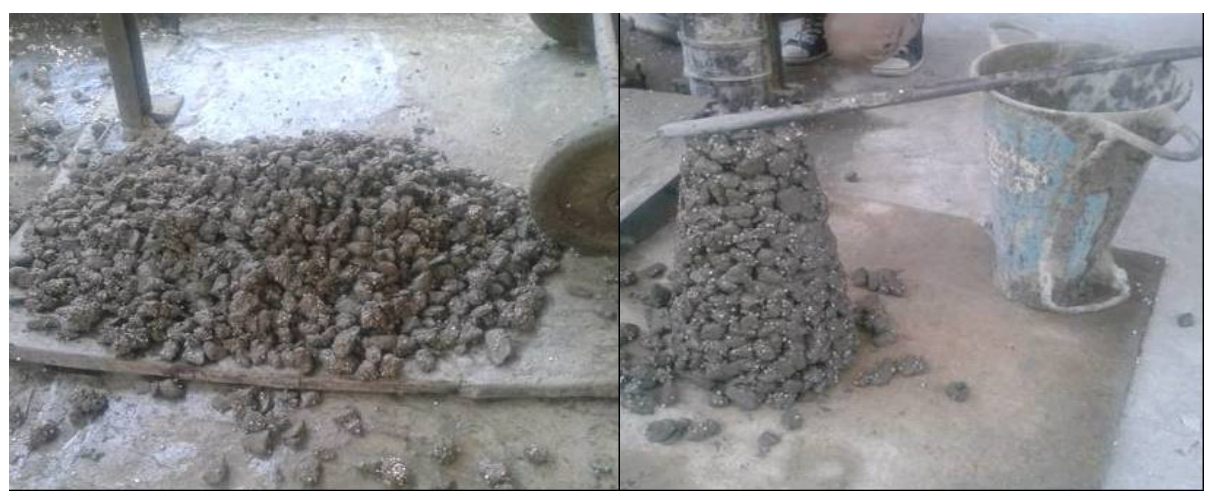

Gambar 8. Rasio agregat semen 4,5 dan fas 0,25

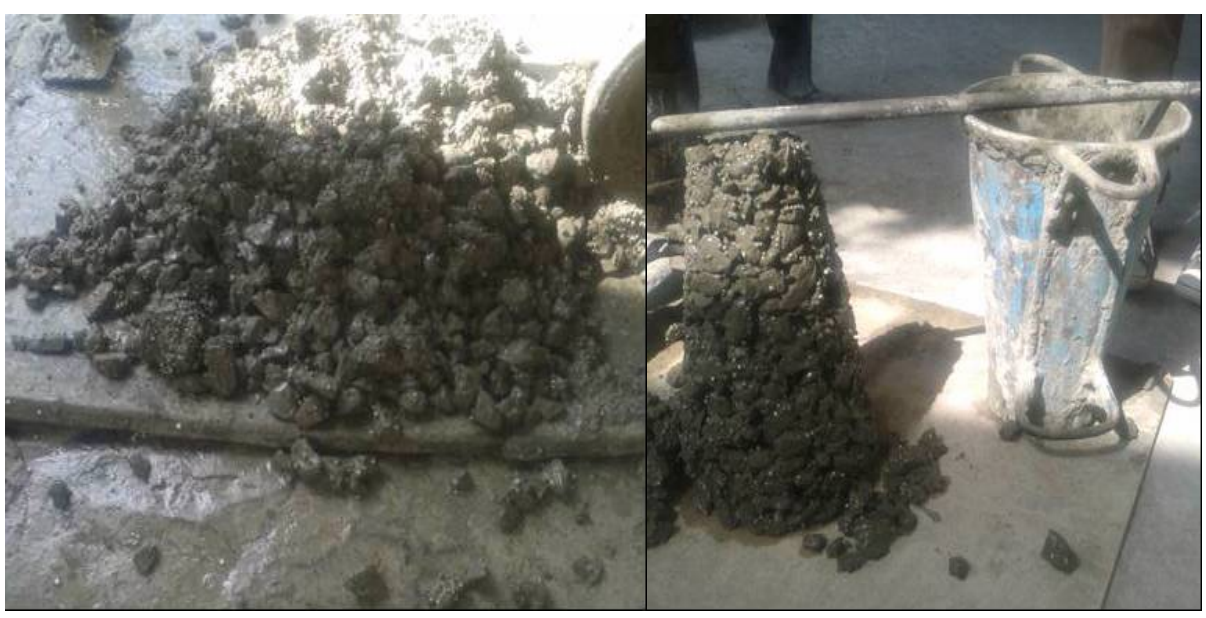

Gambar 9. Rasio agregat semen 4,5 dan fas 0,3

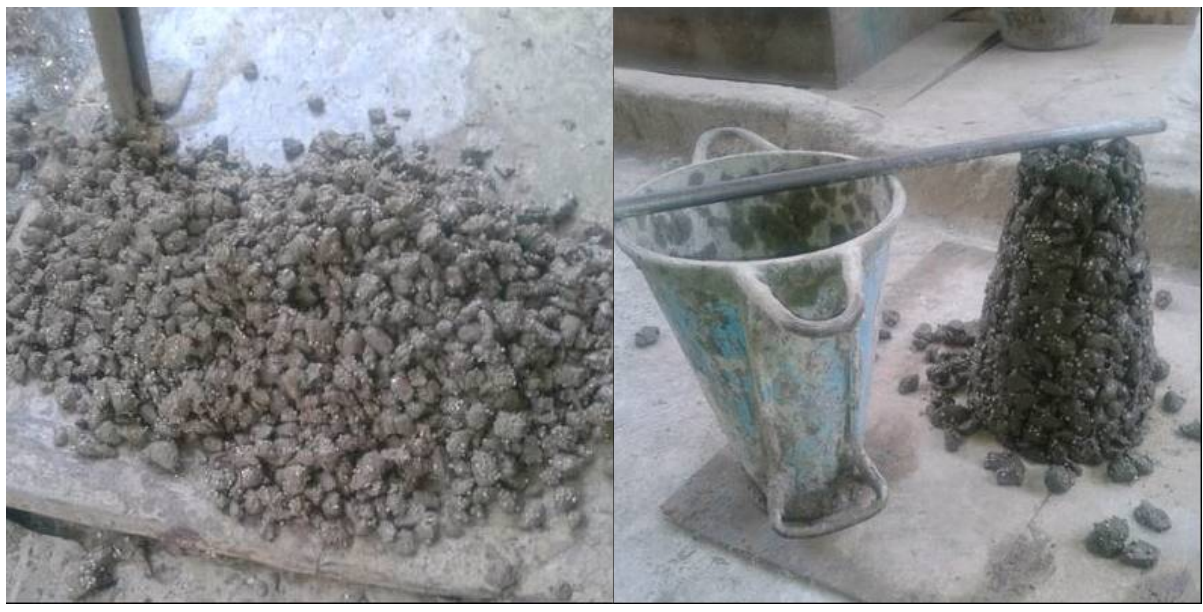

Gambar 10. Rasio agregat semen 5 dan fas 0,25 


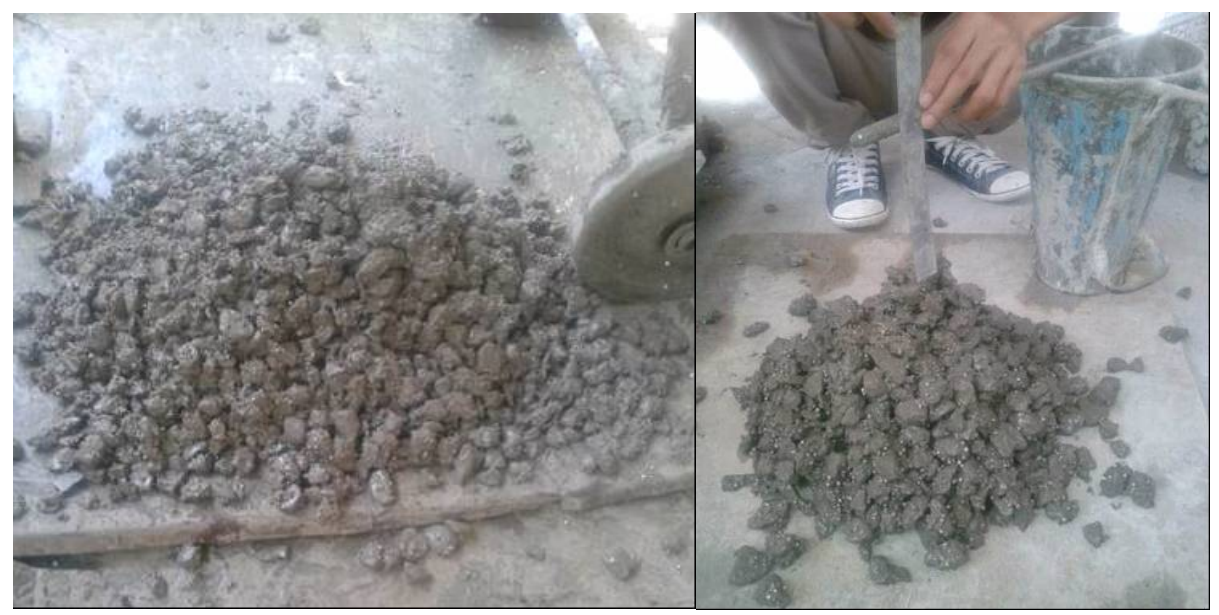

Gambar 11. Rasio agregat semen 5 dan fas 0,3

\subsection{Kuat Tekan Beton Porous}

Kuat tekan beton porous dengan bahan pengisi styrofoam pada berbagai rasio agregat semen, faktor air semen (fas), adalah seperti Tabel 4 berikut ini.

Tabel 4. Kuat tekan beton porous

\begin{tabular}{|c|c|c|c|}
\hline $\begin{array}{c}\text { No. } \\
\text { Urut }\end{array}$ & $\begin{array}{c}\text { Rasio } \\
\text { Agregat/ } \\
\text { semen }\end{array}$ & FAS & $\begin{array}{c}\text { Kuat Tekan } \\
\text { Rata-rata } \\
\text { (MPa) }\end{array}$ \\
\hline 1 & \multirow{2}{*}{3,5} & 0,25 & 8,87 \\
\cline { 1 - 1 } 2 & \multirow{2}{*}{4} & 0,30 & 14,97 \\
\hline 3 & \multirow{2}{*}{4,5} & 0,25 & 8,13 \\
\hline 4 & & 0,30 & 11,13 \\
\hline 5 & \multirow{2}{*}{5} & 0,25 & 7,76 \\
\hline 6 & \multirow{2}{*}{5} & 0,30 & 10,25 \\
\hline 7 & & 0,30 & 7,37 \\
\hline 8 & \multirow{2}{*}{5} & & 8,11 \\
\hline
\end{tabular}

Dari Tabel 4 dapat dilihat bahwa kuat tekan beton porous dengan bahan pengisi styrofoam, pada faktor air semen (fas) 0,25 dan 0,30, mengalami penurunan seiring dengan meningkatnya rasio agregat/semen. Kuat tekan tertinggi terjadi pada rasio agregat/semen 3,5, dan kuat tekan terendah terjadi pada rasio agregat/semen 5,0. Hal ini terjadi karena semakin kecil rasio agregat/semen jumlah semennya semakin banyak. Kuat tekan tertinggi akan terjadi pada campuran dengan jumlah semen yang lebih banyak 
selama jumlah semen yang dipakai belum mencapai optimum. Kuat tekan akan turun jika jumlah semen yang dipakai melebihi optimum diakibatkan oleh penggunaan air yang terlalu banyak walaupun faktor air semen (fas) tetap. Untuk lebih jelasnya dapat dilihat pada Gambar 12.

Dari Gambar 12 juga dapat dilihat bahwa kuat tekan beton porous dengan faktor air semen (fas) 0,25 lebih rendah dari fas 0,30. Kondisi ini terjadi pada campuran yang tanpa dan dengan penambahan styrofoam, dan juga pada semua rasio agregat/semen. Secara umum kuat tekan tertinggi akan terjadi pada faktor air semen (fas) terendah selama campuran masih bisa dipadatkan dan air yang tersedia cukup untuk proses hidrasi. Pada faktor air semen (fas) 0,25 air yang digunakan terlalu sedikit sehingga proses hidrasi kurang sempurna dan mengakibatkan daya rekat pasta terhadap agregat kasar tidak kuat.

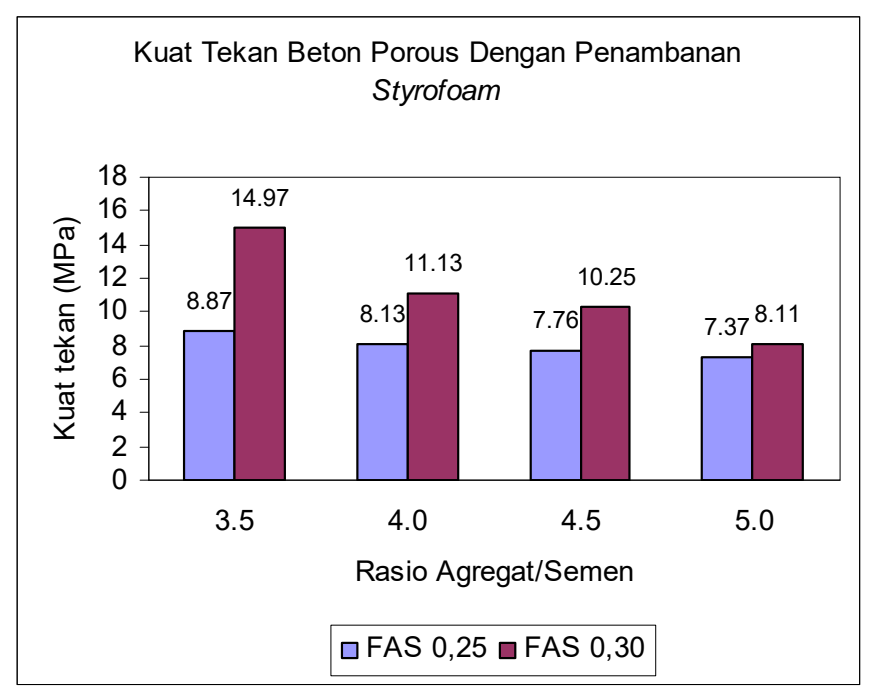

\section{Gambar 12. Kuat tekan beton porous dengan bahan pengisi styrofoam}

Dari hasil penelitian ini didapat kuat tekan beton porous dengan bahan pengisi styrofoam pada faktor air semen (fas) 0,25 terendah sebesar 7,37 $\mathrm{MPa}$ dan tertinggi sebesar 8,87 MPa. Kuat tekan beton porous dengan bahan pengisi styrofoam pada faktor air semen (fas) 0,30 terendah sebesar 8,11 MPa dan tertinggi sebesar 14,97 MPa.

Porositas beton porous dengan bahan pengisi styrofoam pada berbagai rasio agregat semen dan faktor air semen (fas) adalah seperti Tabel 5. Dari Tabel 5 dapat dilihat bahwa porositas beton porous dengan bahan pengisi styrofoam, pada faktor air semen (fas) 0,25 dan 0,30, mengalami peningkatan seiring dengan meningkatnya rasio agregat/semen. Porositas tertinggi terjadi pada rasio agregat/semen 5, dan porositas terendah terjadi pada rasio agregat/semen 3,5. Hal ini terjadi karena semakin besar rasio 
agregat/semen jumlah semennya semakin sedikit. Jumlah semen yang sedikit diikuti dengan jumlah air yang juga sedikit untuk mempertahankan faktor air semen (fas) tetap. Jumlah semen yang sedikit dan jumlah air yang sedikit akan menghasilkan pasta semen yang juga sedikit dan kental sehingga pori-pori antar agregat hanya berisi sedikit pasta dan tidak terjadi aliran pasta ke bagian bawah. Hal ini mengakibatkan porositas beton porous yang dihasilkan menjadi besar. Untuk lebih jelasnya dapat dilihat pada Gambar 13.

Tabel 5. Porositas beton porous dengan bahan pengisi styrofoam

\begin{tabular}{|c|c|c|c|}
\hline $\begin{array}{c}\text { No. } \\
\text { Urut }\end{array}$ & $\begin{array}{c}\text { Rasio } \\
\text { Agregat/ } \\
\text { semen }\end{array}$ & FAS & $\begin{array}{c}\text { Debit } \\
\text { Rata-rata } \\
\left(\mathrm{ltr} / \mathrm{dt}_{\mathrm{m}} \mathrm{m}^{2}\right.\end{array}$ \\
\hline 1 & \multirow{2}{*}{3,5} & 0,25 & 33,14 \\
\hline 2 & & 0,30 & 7,63 \\
\hline 3 & \multirow{2}{*}{4} & 0,25 & 34,90 \\
\hline 4 & \multirow{2}{*}{4,5} & 0,30 & 19,52 \\
\hline 5 & \multirow{2}{*}{5} & 0,25 & 36,23 \\
\hline 6 & \multirow{2}{*}{5} & 0,30 & 32,94 \\
\hline 7 & & 0,25 & 37,00 \\
\hline 8 & & 0,30 & 33,35 \\
\hline
\end{tabular}

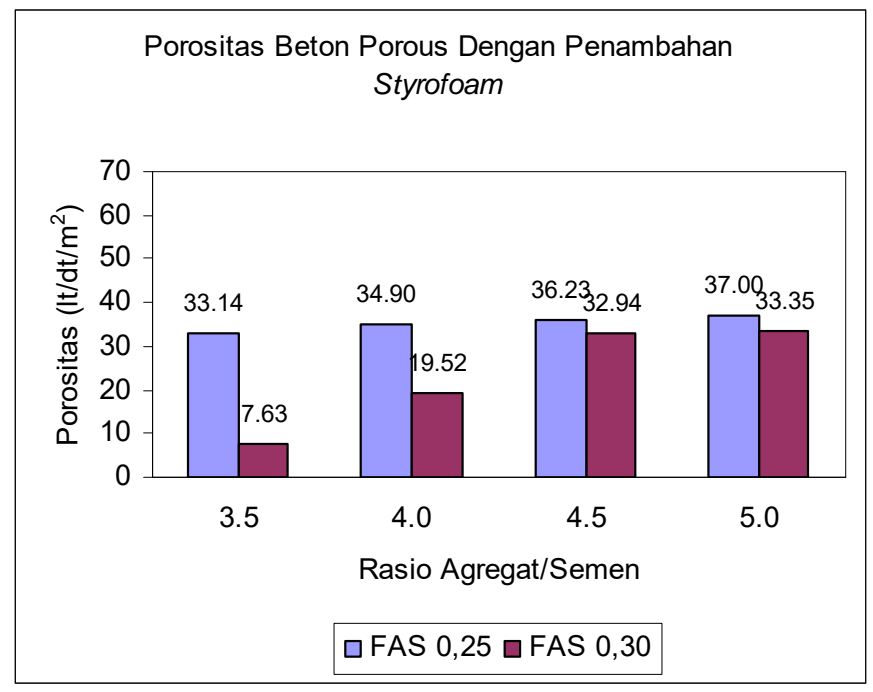

Gambar 13. Porositas beton porous dengan bahan pengisi styrofoam 
Dari Gambar 13 juga dapat dilihat bahwa porositas beton porous dengan faktor air semen (fas) 0,25 lebih tinggi dari fas 0,30. Kondisi ini terjadi pada semua rasio agregat/semen. Pada faktor air semen (fas) 0,25 air yang digunakan lebih sedikit dari faktor air semen (fas) 0,30. Pada faktor air semen (fas) 0,30 campuran terlalu encer sehingga pasta semen mengalir ke bagian bawah dan menutupi pori-pori antar agregat sehingga porositasnya menjadi menurun.

Dari hasil penelitian ini didapat porositas beton porous dengan bahan pengisi styrofoam pada faktor air semen (fas) 0,25 terendah sebesar $33,14 \mathrm{lt} / \mathrm{dt} / \mathrm{m}^{2}$ dan tertinggi sebesar $37,00 \mathrm{lt} / \mathrm{dt} / \mathrm{m}^{2}$. Porositas beton porous dengan bahan pengisi styrofoam pada faktor air semen (fas) 0,30 terendah sebesar $7,63 \mathrm{lt} / \mathrm{dt} / \mathrm{m}^{2}$ dan tertinggi sebesar 33,35 $1 \mathrm{t} / \mathrm{dt} / \mathrm{m}^{2}$.

\subsection{Berat Volume Beton Porous}

Berat volume beton porous dengan bahan pengisi styrofoam pada berbagai rasio agregat semen dan faktor air semen (fas) adalah seperti Tabel 6 berikut ini.

Tabel 6. Berat volume beton porous dengan bahan pengisi styrofoam

\begin{tabular}{|c|c|c|c|}
\hline $\begin{array}{c}\text { No. } \\
\text { Urut }\end{array}$ & $\begin{array}{c}\text { Rasio } \\
\text { Agregat/ } \\
\text { semen }\end{array}$ & FAS & $\begin{array}{c}\text { Berat Volume } \\
\text { Rata-rata } \\
\left(\mathrm{kg} / \mathrm{m}^{3}\right)\end{array}$ \\
\hline 1 & \multirow{2}{*}{3,5} & 0,25 & 1775 \\
\hline 2 & & 0,30 & 1898 \\
\hline 3 & \multirow{2}{*}{4} & 0,25 & 1788 \\
\hline 4 & \multirow{2}{*}{4,5} & 0,30 & 1857 \\
\hline 5 & & 0,25 & 1768 \\
\hline 6 & \multirow{2}{*}{5} & 0,30 & 1813 \\
\hline 7 & \multirow{2}{*}{5} & 0,25 & 1763 \\
\hline \multirow{2nnn}{*nnn}{} & & 0,30 & 1753 \\
\hline
\end{tabular}

Dari Tabel 6 dapat dilihat bahwa berat volume beton porous dengan bahan pengisi styrofoam, pada faktor air semen (fas) 0,25 dan 0,30, secara umum mengalami penurunan seiring dengan meningkatnya rasio agregat/semen. Berat volume tertinggi terjadi pada rasio agregat/semen 3,5, dan berat volume terendah terjadi pada rasio agregat/semen 5,0. Hal ini terjadi karena semakin besar rasio agregat/semen jumlah semennya semakin sedikit. Jumlah semen yang sedikit diikuti dengan jumlah air yang juga sedikit untuk mempertahankan faktor air semen (fas) tetap. Jumlah semen yang 
sedikit dan jumlah air yang sedikit akan menghasilkan berat volume yang lebih rendah karena jumlah agregat tetap untuk semua rasio agregat/semen. Untuk lebih jelasnya dapat dilihat pada Gambar 14.

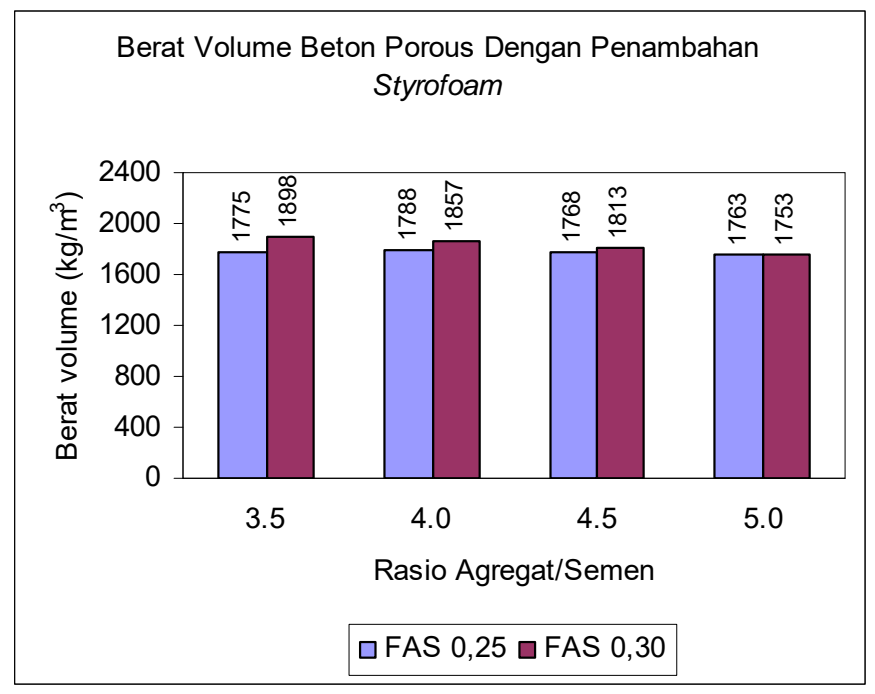

Gambar 14. Berat volume beton porous dengan bahan pengisi styrofoam

\section{KESIMPULAN DAN SARAN}

\subsection{Kesimpulan}

1. Kuat tekan beton porous dengan bahan pengisi styrofoam mengalami penurunan seiring dengan meningkatnya rasio agregat/semen.

2. Kuat tekan beton porous dengan bahan pengisi styrofoam pada faktor air semen (fas) 0,25 lebih rendah dari fas 0,30 .

3. Porositas beton porous dengan bahan pengisi styrofoam mengalami peningkatan seiring dengan meningkatnya rasio agregat/semen.

4. Porositas beton porous dengan bahan pengisi styrofoam pada faktor air semen (fas) 0,25 lebih tinggi dari fas 0,30 .

5. Berat volume beton porous dengan bahan pengisi styrofoam mengalami penurunan seiring dengan meningkatnya rasio agregat/semen.

\subsection{Saran}

1. Perlu dilakukan penelitian pengaruh penambahan styrofoam terhadap daktilitas beton porous. 
2. Perlu dilakukan penelitian lanjutan mengenai pengaruh gradasi agregat kasar terhadap kuat tekan dan porositas beton porous.

\section{DAFTAR PUSTAKA}

1. Abadjieva, T., Sephiri, P., (2000), Investigations on Some Properties of No-Fines Concrete, University of Botswana, Botswana, http://www.irbnet.de/daten/iconda/CIB8837.pdf

2. Anonim, 2004, CIP-38 Pervious Concrete, NRMCA (National Ready Mixed Concrete Association), Silver Spring, Maryland, http://www.nrmca.org/aboutconcrete/cips/38p.pdf

3. Anonim, 2010, ACI 522R-10, Repot on Pervious Concrete, American Concrete Institute, Farmington Hills, MI, USA.

4. Anonim, SNI 03-1974-1990, Metode Pengujian Kuat Tekan Beton, Puslitbang Permukiman, Departemen Pekerjaan Umum.

5. Cowd, M.A., 1991, Kimia Polimer, Penerbit ITB, Bandung.

6. Harber, P.J., 2005, Applicability of No-Fines Concrete as a Road Pavement, Research Project, Bachelor of Engineering, Faculty of Engineering and Surveying, University of Southern Queensland, https://eprints.usq.edu.au/472/1/PaulHARBER-2005.pdf

7. Neville, A.M., Brooks, J.J., 2010, Concrete Technology, Second Edition, Pearson Education Limited, Essex, England.

8. Tjokrodimuljo, K., 1996, Teknologi Beton, Buku Ajar, Jurusan Teknik Sipil, Fakultas Teknik, Universitas Gadjah Mada, Yogyakarta. 